\title{
SISTEM ANALISIS DIAGNOSA PENYAKIT TANAMAN ANGGUR DENGAN PENDEKATAN CERTAINTY FACTOR BERBASIS ANDROID
}

\author{
Radinal Apriyanto ${ }^{1)}$, Moh. Ahsan ${ }^{2)}$ \\ ${ }^{1,2)}$ Teknik Informatika, Universitas Kanjuruhan Malang, Indonesia \\ email: radinal24apriyanto@gmail.com ${ }^{I)}$,ahsan@unikama.ac.id ${ }^{2)}$
}

\begin{abstract}
Abstrak
Kabupaten Malang lebih tepatnya di Kecamatan Purwodadi merupakan salah satu kebun anggur terbesar di Indonesia. Bahkan merupakan kebun anggur dengan hasil terbaik sehingga dikirim ke seluruh kota di Indonesia. Potensi perkebunan anggur menjadikan warga setempat memiliki peluang untuk mendapatkan pekerjaan dan lebih produktif. Secara spesifik buah anggur adalah tanaman buah berupa perdu merambat. Buah anggur termasuk ke dalam keluarga Vitaceae. Buah anggur dibuat minuman anggur, minyak biji anggur, jus anggur, jelly, dan kismis, atau dimakan langsung. Buah anggur ini mengandung banyak senyawa polifenol dan resveratol yang sangat berperan aktif dalam metabolisme tubuh, juga mampu mencegah terbentuknya sel kanker dan berbagai penyakit lainnya. Namun buah anggur sering mengalami serangan penyakit sehingga berakibat $40-70 \%$ pertumbuhan tanaman anggur terganggu. Serangan hama pada tanaman anggur di Purwodadi tidak diimbangi dengan pengetahuan bagi petani baru untuk mengatasinya, sehingga buah kisut, jumlah buah tidak maksimal, rasa buah tidak manis dan terjadi fase generative. Oleh sebab itu penelitian ini bertujuan untuk membantu petani di kebun anggur Purwodadi dalam penentuan penyakit dan memberikan solusinya, karena seringnya terjadi serangan hama dan penyakit pada tanaman anggur. Menggunakan sistem analisis diagnosa dengan menggunakan metode certainty faktor berbasis android diharapkan dapat memudahkan petani baru mengerti tentang ciri-ciri tanaman anggur yang terkena hama dan penyakit serta cara mengatasinya.
\end{abstract}

\section{Kata Kunci :}

Sistem Analisis, Anggur, Certainty Factor, Android.

\begin{abstract}
Malang Regency more precisely in Purwodadi District is one of biggest vineyard and best result to be sent to various City in Indonesia. Given the potential of these wineries, local residents have the opportunity to find work. Grape fruit is a fruit shrub in the form of vines that belong to the family Vitaceae. The fruit is usually used to make grape juice, jelly, wine, grape seed oil and raisins, or eaten directly. This fruit is also known for containing many polyphenolic and resveratol compounds that play an active role in various body metabolism, and can prevent the formation of cancer cells and various other diseases. As a result of pests attacking vineyards in Purwodadi and a lack of knowledge for new farmers to overcome them, grape growth can be disturbed up to 40-70\%, shriveled fruit, not maximal fruit, fruit taste is not sweet and generative phase occurs. This study aims to assist farmers in Purwodadi vineyards in the determination of the disease and provide a solution, because of frequent pest and disease attacks on grapevines. Using a diagnostic analysis system using certainty based factor android method is expected to facilitate new farmers understand about the characteristics of grape plants affected by pests and diseases and how to overcome them.
\end{abstract}

Keywords :

Analysis System, Wine, Certainty Factor, Android.

\section{PENDAHULUAN}

Indonesia merupakan negara yang kaya akan keragaman flora. Iklim Indonesia sangat cocok untuk melakukan aktifitas perkebunan. Perkebunan dapat dijadikan sebagai salah satu sumber pendapatan negara, sekaligus penyedia lapangan kerja untuk masyarakat. Secara umum budi daya perkebunan merupakan kegiatan usaha tanaman yang hasilnya dapat diekspor atau digunakan sebagai bahan baku industry. Perkebunan telah mampu menunjukkan peran dan keuntungannya dalam perekonomian nasional ini dibuktikan dari tingkat perekonomian 
indonesia.

Kabupaten Malang lebih tepatnya di Kecamatan Purwodadi merupakan salah satu kebun anggur terbesar dan terbaik hasilnya untuk di kirim ke berbagai Kota di Indonesia. Dengan adanya potensi perkebunan anggur ini membuat warga setempat memiliki peluang mendapatkan pekerjaan. Buah anggur merupakan tanaman buah berupa perdu merambat yang termasuk ke dalam keluarga Vitaceae. Buah ini biasanya digunakan untuk membuat jus anggur, jelly, minuman anggur, minyak biji anggur dan kismis, atau dimakan langsung. Buah ini juga dikenal karena mengandung banyak senyawa polifenol dan resveratol yang berperan aktif dalam berbagai metabolisme tubuh, serta mampu mencegah terbentuknya sel kanker dan berbagai penyakit lainnya. (Pranitasari,2011).

Sejak tahun 2000, Kebun Anggur Purwodadi membangun komoditas perkebunan di Kabupaten Purwodadi dan mampu membantu perekonomian sekitar karena memberikan kontribusi penerimaan pesananan berupa buah anggur antar kota berupa permintaan anggur yang cukup besar. Berdasarkan hasil wawancara dari Bapak Gustari selaku pengelola kebun anggur di Purwodadi didapatkan data berupa jumlah pengiriman ke luar kota pada tahun 2015 mencapai +-28000 Kg. ini menunjukan bahwa kebun anggur purwadadi menjadi salah satu pemasok buah anggur terbesar di wilayah Jawa Timur.

Akibat dari serangan hama yang menyerang tanaman anggur di Purwodadi dan kurangnya pengetahuan bagi petani baru untuk mengatasinya, pertumbuhan tanaman anggur dapat terganggu hingga 40-70\%, buah kisut, jumlah buah tidak maksimal, rasa buah tidak manis dan terjadi fase generative. Penelitian ini bertujuan untuk membantu petani di kebun anggur Purwodadi dalam penentuan penyakit dan memberikan solusinya, karena seringnya terjadi serangan hama dan penyakit pada tanaman anggur. Menggunakan sistem analisis dengan menggunakan metode certainty faktor berbasis android diharapkan dapat memudahkan petani baru mengerti tentang ciri-ciri tanaman anggur yang terkena hama dan penyakit serta cara mengatasinya.

Berdasarkan Jurnal Nasional Pendidikan Teknik Informatika yang ditulis oleh Ida Nirmala tahun 2014, dengan Judul Sistem Pakar Diagnosa Awal Penyakit Kulit pada Sapi dengan Metode Certainty Faktor mengatakan bahwa metode certainty faktor ini dapat digunakan untuk memperkuat keyakinan user, karena di dalam metode ini menggunakan nilai kepastian dalam melakukan perhitungan. Metode certainty factor juga tidak akan mengeksekusi yang diinputkan user jika user menginputkan data yang tidak diperbolehkan (illegal values). Jadi dalam melakukan diagnosa dengan menggunakan metode ini kemungkinan terjadinya kesalahan sangat kecil.

Berdasarkan pembahasan di atas maka dapat diambil penelitian dengan judul sistem analisis diagnosa penyakit pada tanaman anggur dengan pendekatan certainty faktor berbasis android.

\section{METODE / ALGORITMA}

\subsection{Pengertian Sistem Analisis}

Sistem adalah kumpulan dari komponen-komponen peralatan model requirement, function dan interface. Sedangkan sistem informasi merupakan kombinasi teratur apapun dari sumber daya manusia, hardware, software, data dan jaringan. (Sukadi, 2013). Suatu sistem mempunyai karakteristik atau sifat-sifat yang tertentu

Pengertian analisis menurut sukadi, 2013 adalah kajian yang dilaksanakan terhadap sebuah bahasa guna meneliti struktur bahasa tersebut secara mendalam. Sedangkan pada kegiatan laboratorium, kata analisis atau analisis dapat juga berarti kegiatan yang dilakukan di laboratorium untuk memeriksa kandungan suatu zat dalam cuplikan. Namun, dalam perkembangannya, penggunaan kata analisis atau analisis mendapat sorotan dari kalangan 
akademisis, terutama kalangan ahli bahasa. Penggunaan yang seharusnya adalah kata analisis. hal ini dikarenakan kata analisis merupakan kata serapan dari bahasa asing (inggris) yaitu analisys. Dari akhiran -isys bila diserap ke dalam bahasa Indonesia menjadi -isis.

\subsection{Tanaman Anggur}

Buah anggur adalah salah satu tumbuhan merambat. Buah ini biasanya dikonsumsi langsung atau bisa juga diolah menjadi jus atau untuk bahan campuran makanan lainnya. Buah ini juga bisa diolah menjadi kismis. Rasanya manis dan sedikit kecut. Bentuknya juga bulat dan ada juga yang lonjong dan warnanya bervariasi. Ada yang warna merah, ungu, dan hijau. Buah anggur mengandung vitamin yang dapat mencegah terkena kanker dan juga penyakit lainnya. Selain itu juga bermanfaat sebagai anti radikal bebas. (Widya, L. 2012).

\subsection{Manfaat Buah Anggur}

Buah anggur ini mengandung vitamin B1 sebanyak 0,069 mg, vitamin B2 sekitar 0,07 mg, vitamin b3 sekitar $0,188 \mathrm{mg}$, asam pantotenat mencapai $0,05 \mathrm{mg}$, folat memenuhi $1 \%$ kebutuhan vitamin $\mathrm{B} 9$ harian, vitamin $\mathrm{C}$ berjumlah $10,8 \mathrm{mg}$, dan vitamin $\mathrm{K}$ yang mengasup $21 \%$ kebutuhan harian manusia. (Amik, K. 2012).

Para ahli menggagaskan adanya golongan senyawa metabolit sekunder seperti flavonoid dan antosianin dalam buah ini mampu membantu mengoptimalkan fungsi sel endoteilal dalam memperlancar aliran darah dalam arteri terhubung dengan tindakan terhadap sel-sel otot halus. Dengan demikian risiko terserang penyakit jantung berkurang.

Menurut Ida Bagus, 2012 mengatakan bahwa manfaat tanaman anggur jika dikonsumsi yaitu:

1. Mencegah Kanker Payudara

Zat kimia dalam anggur yang bernama reservatol akan bertugas menghambat perkembangan tumor atau sel kanker dalam tubuh manusia. Senyawa tersebut sebetulnya lebih menguntungkan wanita dalam hal pencegahan penyakit kanker payudara.

2. Mengobati Sembelit

Sembelit atau istilah medisnya konstipasi adalah kondisi dimana sistem pencernaan manusia tidak dapat mengolah unsur makanan yang mengandung serat berlebih atau memiliki partikel substansi yang sulit dihancurkan sehingga zat sisa yang semestinya dikeluarkan menjadi tidak ada, untuk itu cobalah minum jus anggur ketika mengalami sembelit. Kandungan di dalamnya akan membantu pergerakan usus dalam mencerna makanan menjadi lebih stabil dan lancar.

3. Meringankan Sakit Kepala Sebelah

Tiba-tiba merasakan sakit kepala sebelah yang mencengkeram dapat mengganggu aktivitas Anda. Kalau sudah begitu, jangan terburu-buru minum obat karena anggur siap membantu meredakan rasa sakit yang dirasakan..

4. Mencegah Rambut Rontok

Para pakar kecantikan telah meramu sebuah vitamin yang terbuat dari bahan baku berupa ekstrak buah anggur, vitamin ini difungsikan untuk menjaga kesehatan rambut dan menjauhi dari segala risiko kerusakan seperti rambut rontok.

5. Masker Penghilang Jerawat

jus anggur dapat dijadikan sebuah alternatif pilihan sebagai penghilang jerawat. Dengan menjadikan jus anggur sebagai masker wajah.

\subsection{Hama dan Penyakit Tanaman Anggur}

Salah satu masalah dalam usaha peningkatan mutu dan produksi anggur adalah serangan hama dan penyakit pada daun, tunas, sulur dan buah anggur. Pada tanaman anggur terdapat 
beberapa penyakit yang masing-masing menyerang bagian tanaman tertentu dengan gejala dan cara serangan yang berbeda-beda, tergantung jenis penyebabnya

Pengetahuan tentang sifat masing-masing penyakit sangat dibutuhkan untuk pengambilan tindakan pengendalian yang efektif dan efisien. Sejalan dengan perkembangan usaha-tani anggur, tentunya diperlukan informasi tentang jenis dan karakter penyakit pada tanaman anggur serta cara pengendaliannya. Cara pengendalian OPT (Organisme Pengganggu Tanaman) pada anggur perlu memperhatikan dan menjaga kelestarian lingkungan karena umumnya tanaman anggur ditanam di pekarangan. (Riayani, S. 2011).

\subsection{Hama Tanaman Anggur}

Menurut Widya, L. (2012) hama yang menyerang tanaman anggur antara lain:

1. Rayap

Hewan ini lebih suka menyerang stek yang belum atau baru saja tumbuh dan pohon yang kurang sehat.

2. Burung, tikus, tupai, kelelawar dan musang

Hama ini menyerang buah, khusunya pada waktu menjelang buah masak.

3. Ulat Kantung

Ulat kantung sering mengganggu daun anggur, yaitu dengan membuat lubang-lubang pada lembaran daun. Hama ini tinggal dalam kepompong seperti kerucut.

4. Kumbang Daun

Binatang kumbang suka menyerang daun dengan membuat lubang-lubang pada lembaran daunnya. Binatang kumbang yang menyerang ini yang berwarna hitam atau coklat.

5. Tungau atau Gurem Putih

bercak-bercak kuning pada daun dan berubah hitam, akibatnya kerdil dan buah berkurang. Pengendalian.

6. Penggerek Batang

Hama ini menyerang batang dan cabang yang kurang sehat sehingga mengakibatkan bagian yang diserang sering mengeluarkan lendir dan akhirnya akan mati.

\subsection{Penyakit Tanaman Anggur}

Menurut Tika, I. (2012) mengatakan bahwa penyakit yang menyerang pada tanaman anggur antara lain:

1. Penyakit Tepung Palsu atau Embun Berbulu

Penyakit ini merugikan tanaman anggur karena dapat menurunkan produksi buah sampai $70 \%$. Penyakit tepung palsu dan embun berbulu ini seringkali menyerang pada musim hujan dan dengan cepat dapat meluas, terutama setelah hujan pada malam hari. Penyakit ini seringkali ditandai dengan munculnya bercak-bercak kuning kehijauan pada sisi atas daun. Bercak-bercak ini terkadang timbul tidak jelas dan berbatas. Kemudian bercak akan semakin meluas dan berubah menjadi coklat. Ketika cuaca lembab maka akan terjadi lapisan putih bertepung pada sisi di bawah bercak dan lama kelamaan berakibat daun menjadi kering dan rontok.

2. Penyakit Embun Tepung

Penyakit powdery mildew atau embun tepung seringkali muncul pada masa peralihan dari musim kemarau ke musim penghujan. Penyakit embun tepung merupakan jamur yang menyerang daun dan buah anggur.

3. Karat Daun

Kebanyakan penyakit karat daun ini banyak menyerang pada daun-daun tua. Bagian 
bawah daun akan berwana merah jingga hingga merah sawo yang berisi spora jamur. Bagian atas daun akan terlihat hijau kekuningan. Namun jika terjadi serangan yang berat seluruh permukaan bawah daun tertutup oleh lapisan spora hingga akhirnya daun akan rontok. Dengan demikian tanaman akan mempunyai sedikit daun sehingga mengurangi produksi buah.

4. Antraknose

Penyakit Antraknose seringkali menyerang buah yang hampir masak, tunas dan cabangcabang muda dengan bermula pada gejala berupa bintik-bintik coklat yang meluas dan mengendap ke bawah. Kemudian pada bagian tengah bercak timbul massa berwarna jingga (spora).

5. Busuk Buah

Busuk buah ditanda dengan berubahnya warna asli pada buah anggur tersebut. Penyakit seringkali menyerang daerah pertanaman yang buahnya masak. Gejala yang muncul pada stadium awal serangan yaitu merekahnya jaringan bagian dalam kulit kemudian buah yang terinfeksi menjadi mengkerut dan berubah menjadi coklat tua lalu membusuk.

6. Penyakit Gulung Daun

Gulung daun adalah bentuk daun yang tidak simetris. Bagian daun yang terinfeksi akan lebih kecil daripada bagian yang normal atau terlihat seperti tergulung.

\section{HASIL DAN PEMBAHASAN}

\subsection{Analisis Sistem}

Analisis sistem merupakan penjabaran dari suatu sistem informasi yang utuh untyuk meganalisa permasalahan yang terjadi dan kebutuhan sehingga dapat dibuat perbaikannya. Sistem yang dibuat diharapkan dapat membantu petani dalam menentukan penyakit yang menyerang tanaman anggur dan mendapatkan solusinya. Selama ini jika dalam mendignosa penyakit pada tanaman anggur sering kali petani kesusahan dalam menentukan secara pasti anggur yang ditanam terkena penyakit apa dan bagaimana cara mengobatinya. Karena banyaknya gejala yang timbul pada tanaman angggur dan jumlah tanaman anggur yang ditanam tidak sedikit membuat petani kebingungan dalam menentukan penyakit yang menyerang tanaman anggur.

\subsection{Perhitungan Certainty Factor}

Perhitungan menggunakan metode certaity factor ini untuk mengetahui nilai persentasi yang menyerang pada tanaman anggur yang di tanam dan membandingkan nilai persentasi yang dihitung dengan cara manual dengan sistem yang dirancang, sehingga mengetahui berapa persentasi perbedaan pada nilai certainty factor. Berikut perhitugan certainty factor penentuan penyakit tanaman anggur.

Pada perhitungan certainty factor yang harus diperhatikan yaitu lima nilai ketetapan yang ada, meliputi sangat yakin bernilai 1 , yakin bernilai 0,8 , cukup yakin bernilai 0,7 , sedikit yakin bernilai 0,5 , dan tidak yakin bernilai 0 .

Kaidah atau rule penyakit yang menyerang tanaman anggur adalah sebagai berikut:

IF Pucuk atau tunas menjadi kerdil

AND Bagian yang diserang pada tanaman anggur adalah bagian pucuk

AND Bagian bawah daun tertutup tepung berwarna orange

AND Pada permukaan daun terdapat bedak tipis putih kelabu

THEN Powdery Mildew.

Tabel 1: Pembobotan Kriteria 
URL : https://jurnal.machung.ac.id/index.php/kurawal

\begin{tabular}{|l|c|c|c|c|c|}
\hline \multirow{2}{*}{ Pertanyaan } & \multicolumn{5}{|c|}{ Bobot } \\
\cline { 2 - 6 } & $\begin{array}{c}\text { Sangat } \\
\text { Yakin }\end{array}$ & Yakin & $\begin{array}{c}\text { Cukup } \\
\text { Yakin }\end{array}$ & $\begin{array}{c}\text { Sedikit } \\
\text { Yakin }\end{array}$ & $\begin{array}{c}\text { Tidak } \\
\text { Yakin }\end{array}$ \\
\hline $\begin{array}{l}\text { 1. Pucuk atau tunas menjadi } \\
\text { kerdil }\end{array}$ & $\vee$ & & & & \\
\hline $\begin{array}{l}\text { 2.Bagian yang diserang pada } \\
\text { tanaman anggur adalah } \\
\text { bagian pucuk }\end{array}$ & & & & & \\
\hline $\begin{array}{l}\text { 3.Bagian bawah daun } \\
\text { tertutup tepung berwarna } \\
\text { orange }\end{array}$ & & & & & \\
\hline $\begin{array}{l}\text { 4.Pada permukaan daun } \\
\text { terdapat bedak tipis putih } \\
\text { kelabu }\end{array}$ & & & & & \\
\hline
\end{tabular}

Langkah pertama yang dilakukan sebelum melakukan perhitungan certainty factor yaitu menentukan nilai masing masing gejala penyakit tanaman anggur.

$\mathrm{CF}_{\text {pakar }}$ Pucuk atau tunas menjadi kerdil $=0,6$

$\mathrm{CF}_{\text {pakar }}$ Bagian yang diserang pada tanaman anggur adalah bagian pucuk $=0,5$

$\mathrm{CF}_{\text {pakar }}$ Bagian bawah daun tertutup tepung berwarna orange $=0,7$

$\mathrm{CF}_{\text {pakar }}$ Pada permukaan daun terdapat bedak tipis putih kelabu $=0,4$

Kemudian dilanjutkan dengan menentukan nilai pembobotan untuk user atau pengguna aplikasi penentuan penyakit pada tanaman anggur. Nilai pembobotan dari pilihan jawaban user diantaranya sangat yakin nilainya 1 , yakin 0,8 , cukup yakin 0,7 , sedikit yakit yakin 0,5 dan tidak yakin 0 .

Berikut user melakukan pemilihan jawaban, di antaranya:

Langkah kedua yang harus dilakukan yaitu menentukan nilai $\mathrm{CF}$ masing masing dengan cara mengalikan nilai pakar dengan nilai user.

$$
\begin{aligned}
\mathrm{CF}[\mathrm{H}, \mathrm{E}]_{1} & =\mathrm{CF}[\mathrm{H}]_{1} * \mathrm{CF}[\mathrm{E}]_{1} \\
& =0,6 * 1 \\
& =0,6 \\
\mathrm{CF}[\mathrm{H}, \mathrm{E}]_{2} & =\mathrm{CF}[\mathrm{H}]_{2} * \mathrm{CF}[\mathrm{E}]_{2} \\
& =0,5 * 0,5 \\
& =0,25 \\
\mathrm{CF}[\mathrm{H}, \mathrm{E}]_{3} & =\mathrm{CF}[\mathrm{H}]_{3} * \mathrm{CF}[\mathrm{E}]_{3} \\
& =0,7 * 0 \\
\mathrm{CF}[\mathrm{H}, \mathrm{E}]_{4} & =0 \\
& =\mathrm{CF}[\mathrm{H}]_{4} * \mathrm{CF}[\mathrm{E}]_{4} \\
& =0,5 * 0,7 \\
& =0,35
\end{aligned}
$$

Langkah terahir yang harus dilakukan yaitu dengan cara mengkobinasikan masing masing nilai $\mathrm{CF}$ yang sudah di dapat. Pengkobinasian dilakukan dengan cara $\mathrm{CF}[\mathrm{H}, \mathrm{E}]_{1}$ dengan $\mathrm{CF}[\mathrm{H}, \mathrm{E}]_{2}$ : 
$\mathrm{CF}_{\text {combine }} \mathrm{CF}[\mathrm{H}, \mathrm{E}]_{1,2}=\mathrm{CF}[\mathrm{H}, \mathrm{E}]_{1}+\mathrm{CF}[\mathrm{H}, \mathrm{E}]_{2} *\left(1-\mathrm{CF}[\mathrm{H}, \mathrm{E}]_{1}\right)$

$=0,6+0,25 *(1-0,6)$

$=0,6+0,25 * 0,4$

$=0,6+0,1$

$=0,7$

$\mathrm{CF}_{\text {combine }} \mathrm{CF}[\mathrm{H}, \mathrm{E}]_{\text {old }, 3}=\mathrm{CF}[\mathrm{H}, \mathrm{E}]_{\text {old }}+\mathrm{CF}[\mathrm{H}, \mathrm{E}]_{3} *\left(1-\mathrm{CF}[\mathrm{H}, \mathrm{E}]_{\text {old }}\right)$

$=0,7+0 *(1-0,7)$

$=0,7+0 * 0,3$

$=0,7+0$

$=0,7$

$\mathrm{CF}_{\text {combine }} \mathrm{CF}[\mathrm{H}, \mathrm{E}]_{\text {old }, 4}=\mathrm{CF}[\mathrm{H}, \mathrm{E}]_{\text {old }}+\mathrm{CF}[\mathrm{H}, \mathrm{E}]_{4} *\left(1-\mathrm{CF}[\mathrm{H}, \mathrm{E}]_{\text {old }}\right)$

$=0,7+0,35 *(1-0,7)$

$=0,7+0,35 * 0,3$

$=0,7+0,105$

$=0,805$

Langkah paling terahir setelah mendapatkan nilai terahir yaitu menjadikan kedalam bentuk persentase dengan cara mengalikan dengan 100\%. Jadi, Dengan demikian dapat dikatakan bahwa perhitungan Certainty Factor pada penyakit Powdery Mildew memiliki presentasi $0.805 * 100 \%=80,5 \%$.

\subsection{Diagram Konteks}

Digram konteks pada analisis penyakit pada tanaman anggur dengan pendekatan certainty factor berbasis android dapat dilihat pada gambar 1. Pada gambar 1 dapat dijelasakan bahwa jika pengguna sistem akan melakukan diagnosa penyakit pada tanaman anggur maka pengguna sistem terlebih dahulu harus menginputkan identitas setelah itu baru dapat melakukan diagnosa. Diagnosa dilakukan dengan cara memilih gejala penyakit yang timbul pada tanaman anggur. Setelah pengguna sistem melakukan diagnosa maka pengguna sistem dapat menerima hasil diagnosa dan menerima solusi untuk menangani penyakit yang menyerang tanaman anggur. Admin bertugas menginputkan data gejala, data penyakit dan data aturan.

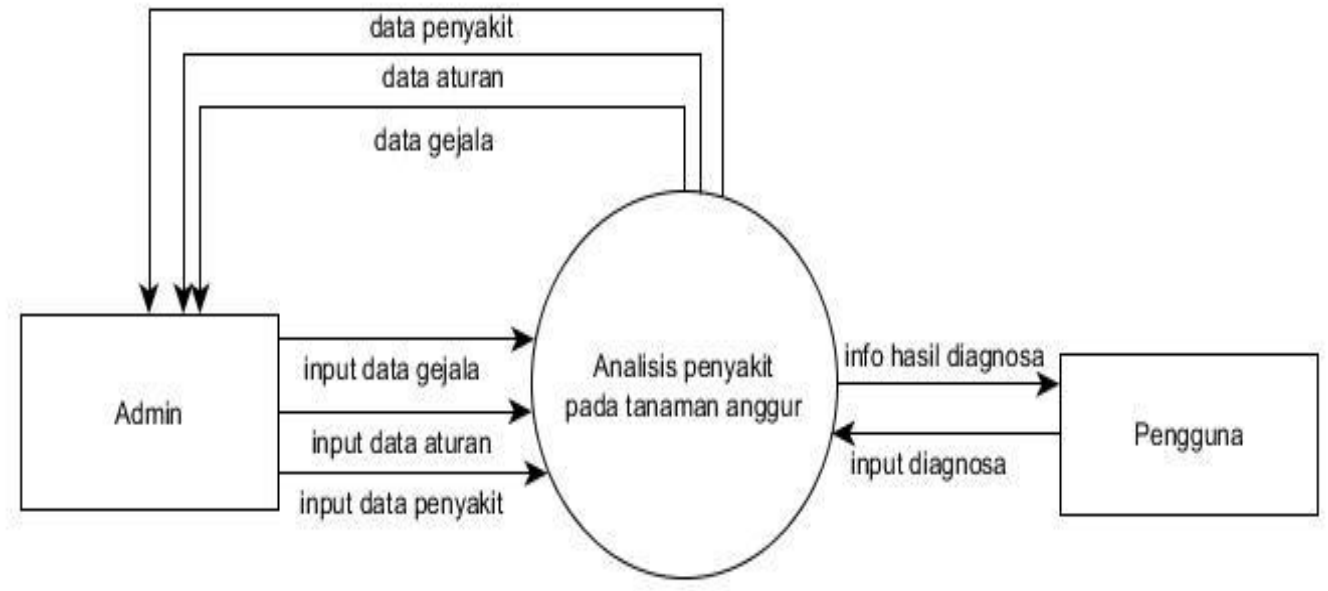

Gambar 1 Diagram Konteks 


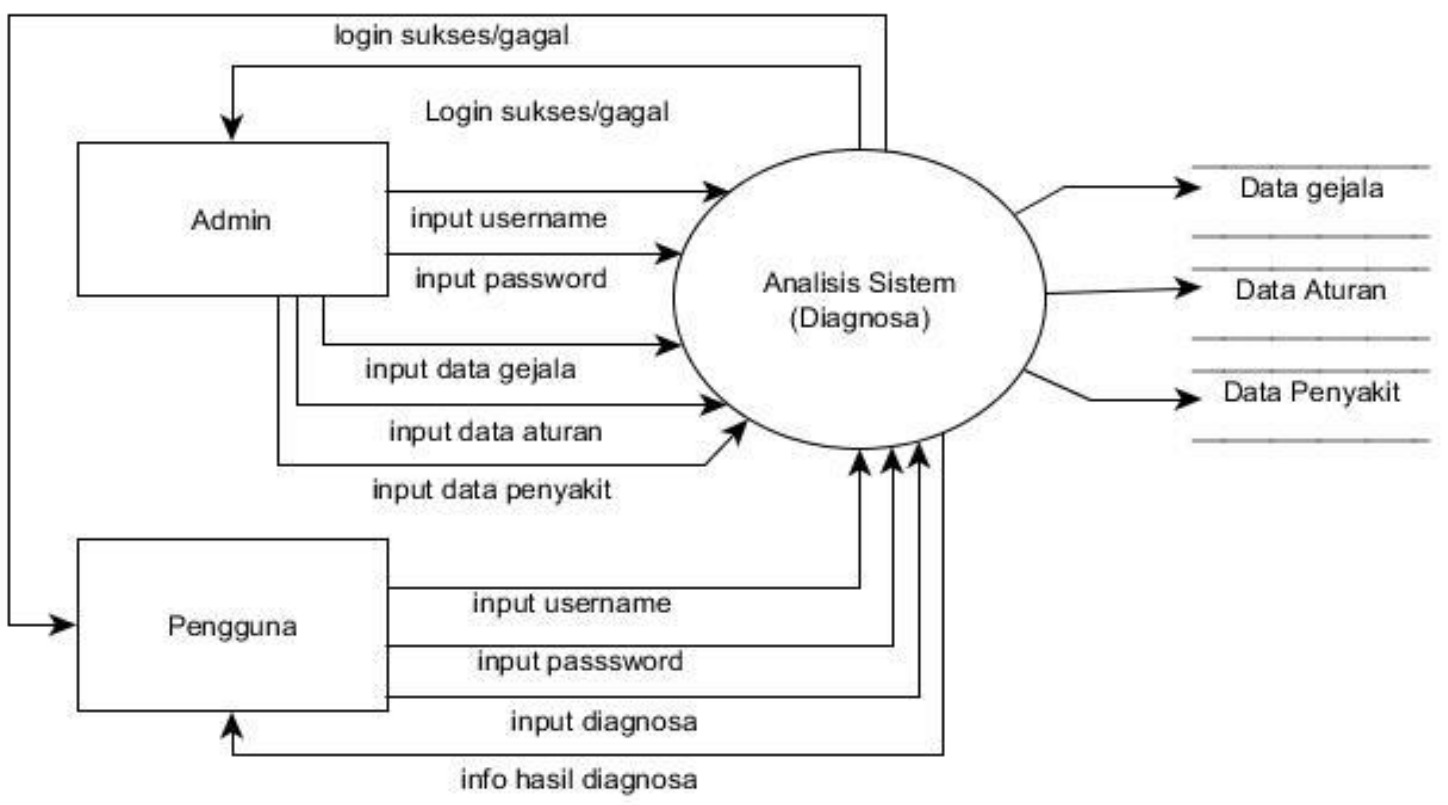

Gambar 2 DFD Level 1

\subsection{Data Flow Diagram Level 1}

Data flow diagram pada analisis penyakit pada tanaman anggur dengan pendekatan certainty factor berbasis android dapat dilihat pada gambar 2

Pada gambar 2 DFD level 1 dapat dijelaskan bahwa:

1. Terdapat 2 yang dapat menjalankan sistem, yaitu pengguna sistem (orang yang membutuhkan sistem untuk mendiagnosa penyakit tanaman anggur).dan admin.

2. Terdapat 1 proses yang ada pada sistem, yaitu: proses analisa.

3. Terdapat 3 penyimpanan database, yaitu: data gejala, data aturan dan data penyakit.

4. Jika pengguna akan menggunakan sistem, pengguna terlebih dahulu login dengan menginputkan username dan password.

5. Setelah pengguna login, selanjutnya akan diarahkan ke menu diagnosa, dimana pada menu ini pengguna sistem akan memilih gejala gejala penyakit yang timbul pada tanaman anggur.

6. Setelah pengguna sistem memilih gejala gejala yang timbul pada tanaman anggur, maka pengguna sistem akan menerima hasil pelaporan berupa penyakit apa yang menyerang tanaman anggur.

7. Setelah menerima penyakit yang menyerang tanaman anggur, selanjutnya pengguna sistem dapat menerima solusi untuk menangani penyakit tanaman anggur yang menyerang.

\subsection{Data Flow Diagram Level 2 Proses 1}

Data flow diagram level 2 proses 1 pada analisis penyakit pada tanaman anggur dengan pendekatan certainty factor berbasis android dapat dilihat pada gambar 3 .

Pada gambar 3 dapat dijelaskan bahwa pengguna menginputkan idetitas untuk menambah user/pengguna, pengguna menginputkan data gejala yang nanti pengguna mendapat info hasil diagnosa penyakit. Proses diagnosa menyimpan data gejala data penyakit, data aturan dan data hasil diagnosa, disimpan pada database masing-masing. 


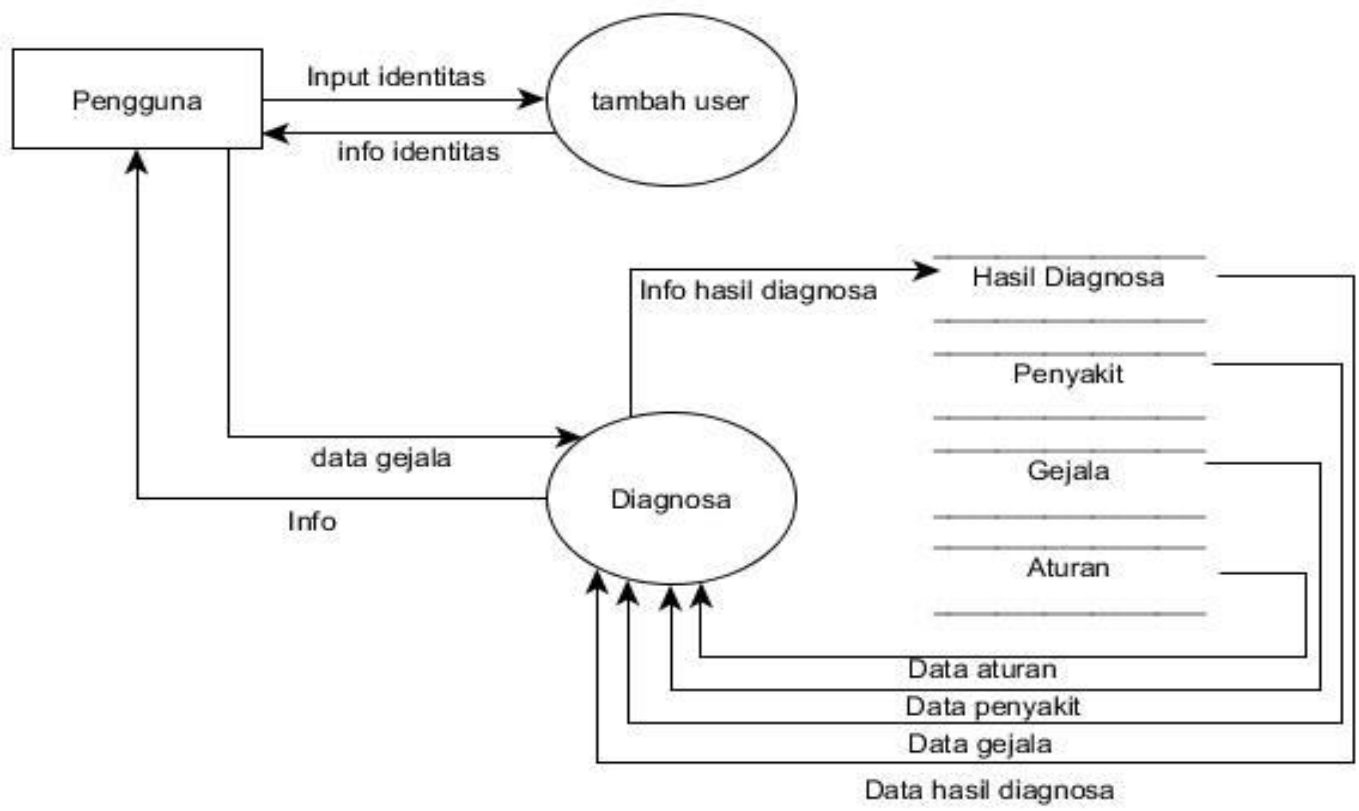

Gambar 3 DFD Level 2 Proses 1

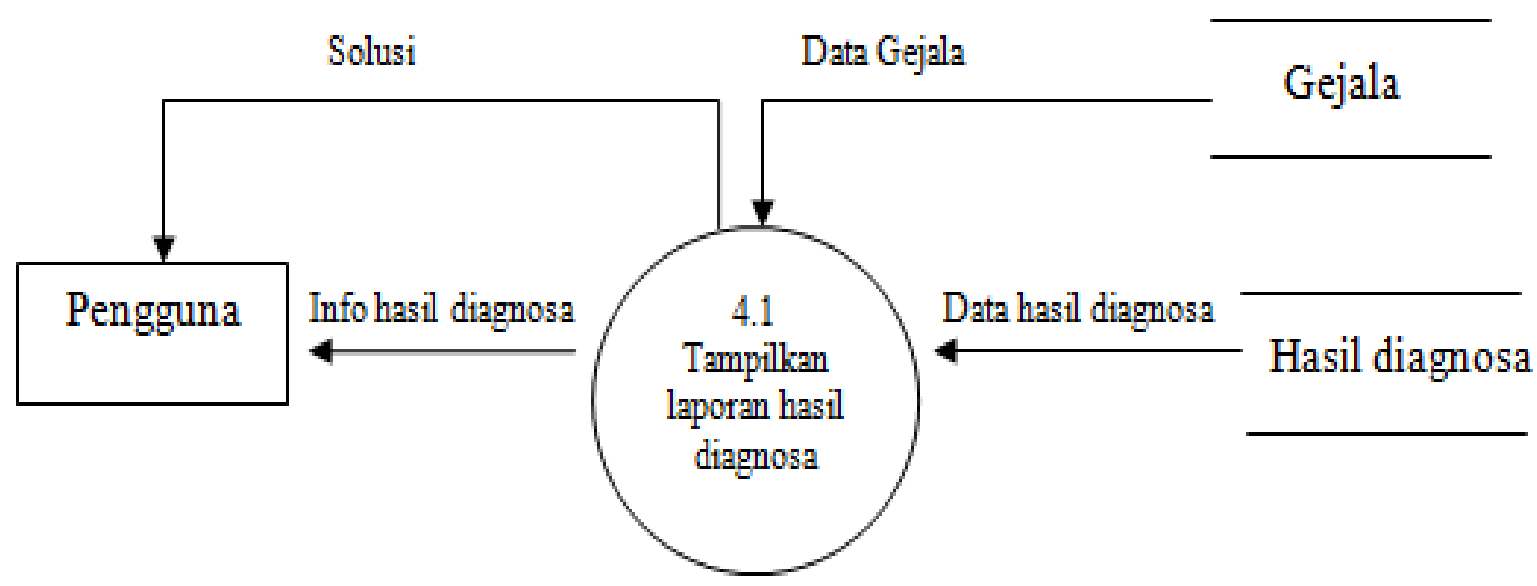

Gambar 4 DFD Level 2 Proses 2

\subsection{Data Flow Diagram Level 2 Proses 2}

Data flow diagram level 2 proses 2 pada analisis penyakit pada tanaman anggur dengan pendekatan certainty factor berbasis android dapat dilihat pada gambar 4

Pada proses hasil analisa ini yang akan menerima hasil analisa penyakit tanaman anggur yaitu pengguna sistem. Pengguna sistem akan menerima informasi penyakit yang menyerang tanaman anggur berdasarkan pemilihan gejala penyakit yang dilakukan pada menu diagnosa penyakit. Setelah pengguna sistem menerima hasil penyakit yang menyerang tanaman anggur, maka pengguna sistem akan mengetahui solusi untuk menangani penyakit tersebut.

\subsection{Flowchart Sistem}

Flowchart sistem merupakan gambaran alur jalannya program yang dibuat. Gambaran ini berupa alur blok blok diagram. Flowhart pengolahan data pada analisis penyakit pada tanaman anggur dengan pendekatan certainty factor berbasis android dapat dilihat pada gambar 5. Dimana dapat dijelaskan bahwa jika admin akan mengolah data yang ada pada 
sistem, terlebih dahulu admin harus masuk dan berhasil login kedalam sistem. Setelah admin berhasil login ke dalam sistem, selanjutnya admin akan memilih akan mengolah data gejala atau data penyakit atau data aturan. Setelah admin mengolah data yang ada di dalam sistem akan otomatis tersimpan dan pengolahan data selesai.

\subsection{Activity Halaman Utama}

Halaman ini merupakan tampilan awal sistem, sebagai halaman pembuka saat sistem dijalankan. Halaman ini berisi judul sistem, activity menu, profil dan keluar.Adapun tampilan utama dapat dilihat pada gambar 6.

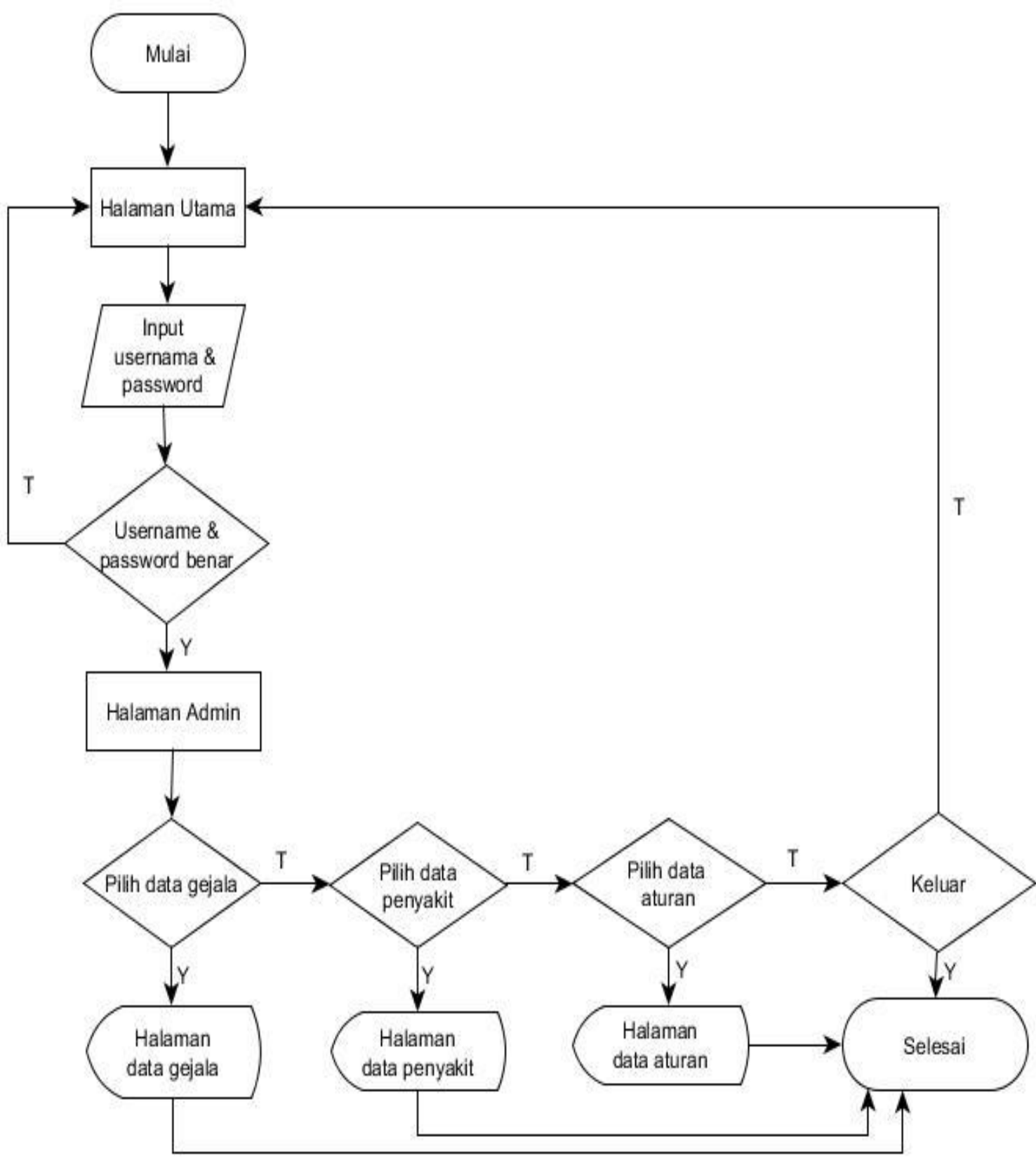

Gambar 5 Flowchart Pengolahan Data 
URL : https://iurnal.machung.ac.id/index.php/kurawal

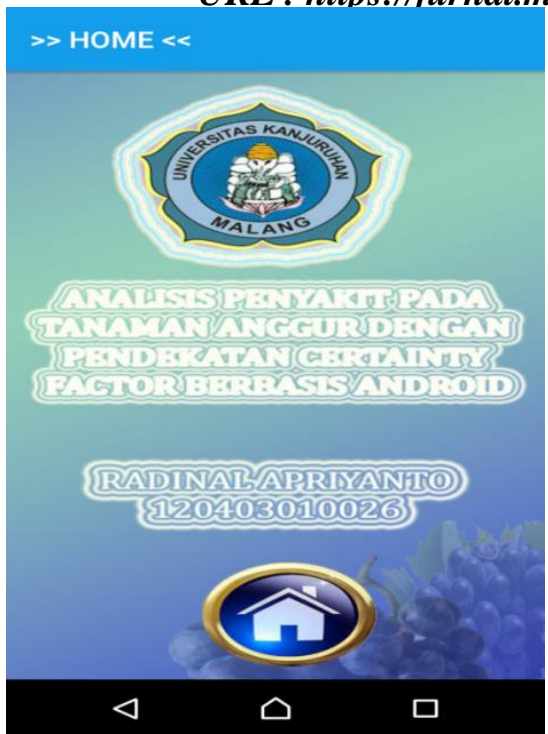

Gambar 6 Activity Halaman Utama

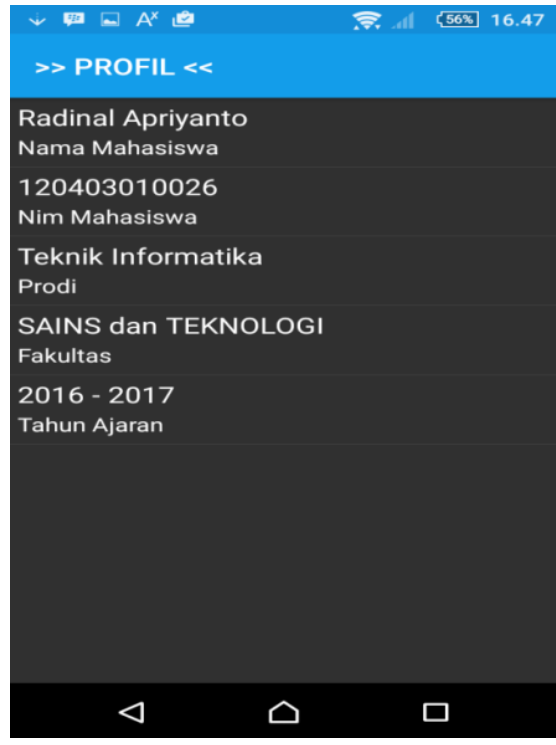

Gambar 7 Activity Halaman Profil

\subsection{Activity Halaman Profil}

Activity Halaman Profil ini berisi biodata perancang yang berisi nama mahasiswa, nim mahasiswa, jurusan mahasiswa, universitas mahasiswa dan tahun ajaran. Adapun tampilan activity profil dapat dilihat pada gambar 7 .

\subsection{Activity Halaman Menu}

Activity Halaman Menu ini berisi activity Home, diagnosa, hasil diagnosa,info dan profil .Adapun tampilan activity menu dapat dilihat pada gambar 8 .

\subsection{Activity Halaman Login User}

Activity halaman login user ini berfungsi untuk user/pengguna sebelum melakukan diagnosa penyakit tanaman anggur. User menginputkan username dan passoword yang sudah dimiliki. Adapun tampilan login user dapat dilihat pada gambar 9 
URL : https://jurnal.machung.ac.id/index.php/kurawal

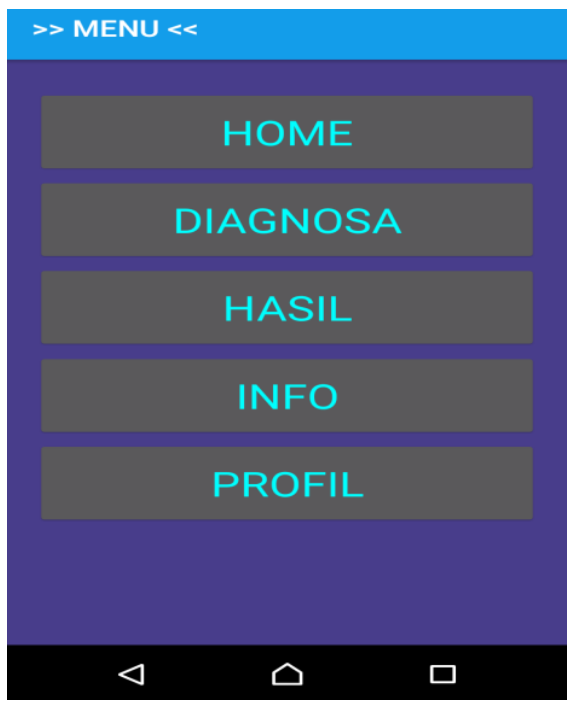

Gambar 8 Activity Halaman Menu

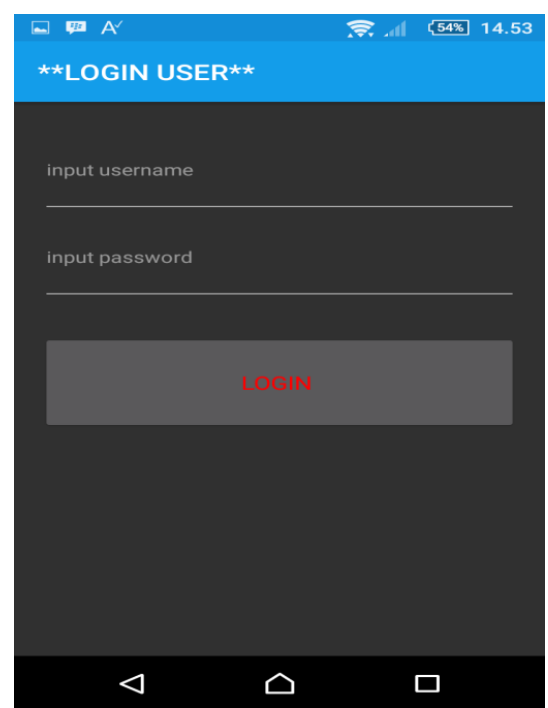

Gambar 9 Activity Halaman Login User

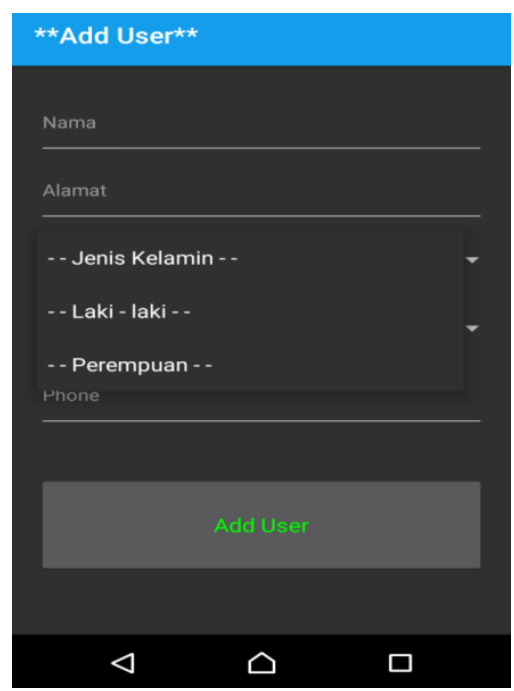

Gambar 10 Activity Halaman Admin 


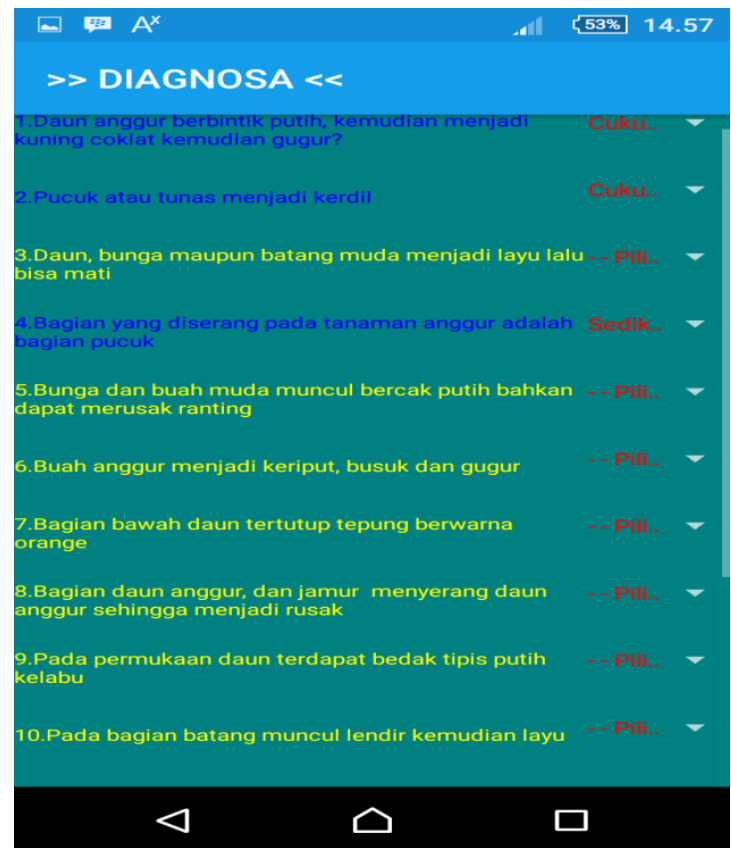

Gambar 11 Activity Halaman Diagnosa

\subsection{Activity Halaman Tambah User}

Activity halaman user ini menampilkan halaman untuk menambah user. User harus mengisi nama alamat, jenis kelamin usia user dan nomor telepon user. Adapun tampilan halaman tambah user dapat dilihat pada gambar 10.

\subsection{Activity Halaman Diagnosa}

Activity Halaman Diagnosa ini berisi gejala-gejala penyakit tanaman anggur Adapun tampilan activity halaman diagnosa dapat dilihat pada gambar 11

\subsection{Activity Halaman Hasil Diagnosa}

Activity Halaman Hasil Diagnosa ini berisi hasil diagnosa penyakit tanaman anggur yang muncul setelah memilih gejala-gejala penyakit.Adapun tampilan activity halaman hasil diagnosa dapat dilihat pada gambar 12 .

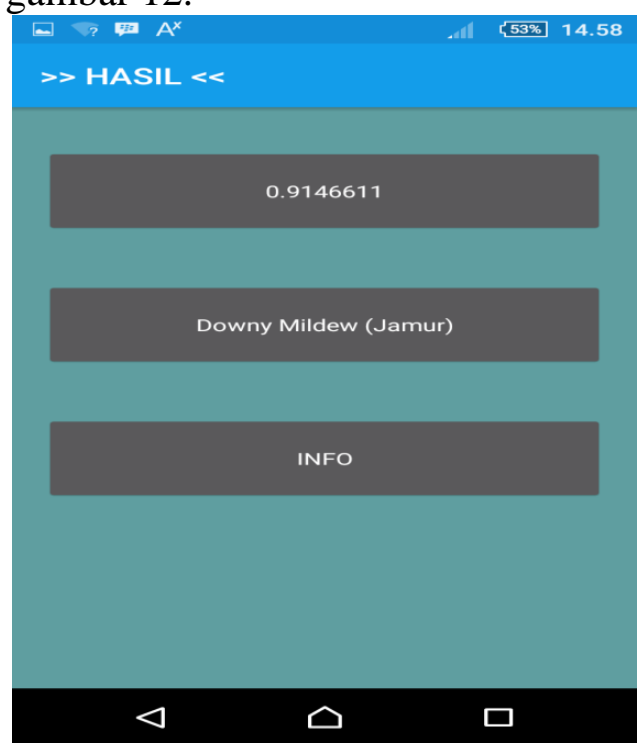

Gambar 12 Activity Halaman Hasil Diagnosa 


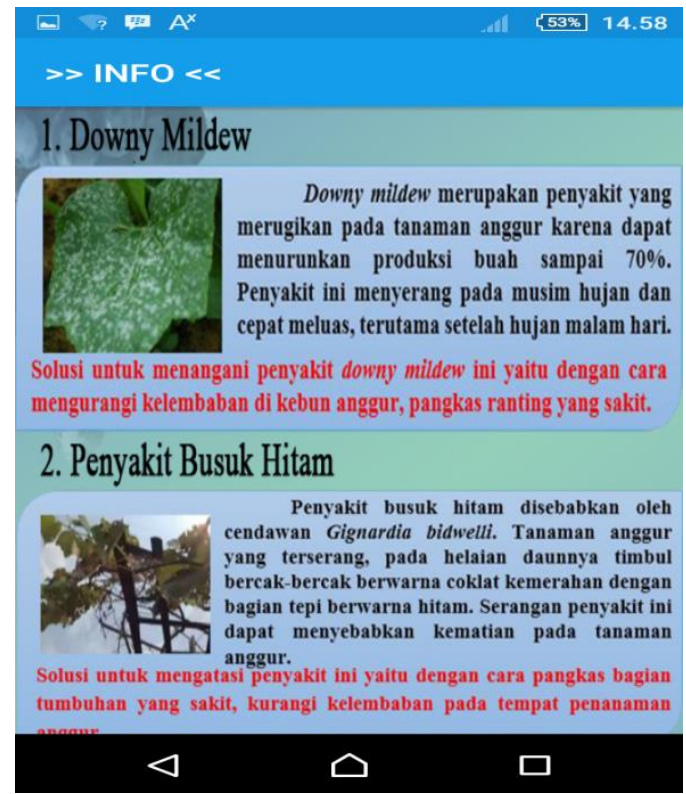

Gambar 13 Activity Halaman Info

\subsection{Activity Halaman Info}

Activity Halaman Info ini menjelaskan tentang info penjelasan tpenyakit tanaman anggur beserta solusi mengatasi penyakit pada tanaman anggur..Adapun tampilan activity halaman info dapat dilihat pada gambar 13.

\section{KESIMPULAN}

\subsection{Kesimpulan}

Dalam proses perancangan serta pembuatan aplikasi ANALISIS PENYAKIT PADA TANAMAN ANGGUR DENGAN PENDEKATAN CERTAINTY FAKTOR BERBASIS ANDROID di kebun anggur Purwodadi dapat diambil kesimpulan :

1. Aplikasi analisis diagnosa penyakit anggur ini menggunakan metode certainty factor, pengguna dapat melakukan diagnosa penyakit anggur lebih awal dan mengetahui solusi dari setiap penyakit anggur dan bagi akademik sebagai referensi bagi mahasiswa dan penelitian lebih lanjut yang berkaitan dengan studi yang dibahas khususnya program studi Teknik Informatika.

2. Aplikasi ini berbasis android yang dapat membantu pengguna untuk melakukan analisis diagnosa penyakit tanaman anggur melalui handphone pengguna masing-masing.

\subsection{Saran}

Saran yang dapat diberikan dari peneliti adalah sebagai berikut:

1. Aplikasi ini dapat bekerja di beberapa sistem mobile, seperti ios dan windows phone.

2. Diharapakan analisis diagnosa penyakit anggur ini diterapkan dengan metode yang lain seperti: metode Dempter Shafer atau Naive Bayes untuk penganalisaan aplikasi ini.

\section{REFERNSI}

[1] Abdul. 2012. Pengujian Perangkat Lunak Dengan Menggunakan Metode White Box Dan Black Box. Semarang.

[2] Afyenni, R. 2014. Perancangan Data Flow Diagram Untuk Sistem Informasi Sekolah. 
Padang.

[3] Amik, K. 2012. Kajian Penerapan Teknologi Usaha Tani Anggur di Kota Probolinggo. Seminar Nasional Kedaulatan Pangan dan Energi Fakultas Pertanian. Universitas Trunojoyo Madura.

[4] Didik. 2012. System Pemesanan Taxi Berbasis Aplikasi Android dan Aplikasi Web. Yogyakarta, Fakultas Sains dan Teknologi Universitas Islam Negeri Yogyakarta.

[5] Dedi. 2014. Pengukuran Usability Sistem Menggunakan Use Questionnaire Pada Aplikasi Android. Palembang.

[6] Dwiastuti, M.E. dan Nurhadi. 1986. Inventarisasi penyakit penting pada tanaman anggur di beberapa sentra produksi. Hortikultura No 20, 660-663.

[7] Edi, Y. 2010. Analisis Data dengan Menggunakan ERD dan Model Konseptual Data Warehouse. Bandung.

[8] Hermawan, S. Stephanus. "Mudah Membuat Aplikasi Android". Halaman 5-7. Andi Offset, Yogyakarta. 2011.

[9] Ida Bagus. 2012. Ipteks Bagi Wilayah (IbW) di Kecamatan Gerokgak. Fakultas Matematika dan Ilmu Pengetahuan Alam. Universitas Pendidikan Ganesha.

[10] Kusrini. 2007. Konsep dan Aplikasi sistem Pendukung Keputusan. Andi : Yogyakarta.

[11] Pranitasari,N.(2011).Anggur (Vitis vinifera L.). Diakses 15 Desember 2014.http://novi-biologi.blogspot.co-l.html

[12] Riayani, S. 2011. Pengaruh Ekstrak Anggur Merah Terhadap Kadar Kolestrol Total Darah Tikus Putih. Fakultas Kedokteran dan Ilmu Kesehatan. Universitas Muhammadiyah Yogyakarta.

[13] Santosa, B. 2007. Data Mining : Teknik Pemanfaatan Data Untuk Keperluan Bisnis Teori dan Aplikasi. Graha Ilmu: Yogyakarta.

[14] Sukadi. 2013. Sistem pakar untuk Mendiagnsis Hama dan Penyakit Tanaman Padi. Indnesian Jurnal on computer Science - Speed (IJCSS). Vol. 10, No.2

[15] Supardi, Yuniar., Pascal dan Flowchart, Dinastindo, Jakarta, 2000.

[16] Supriyanto, A., 2011, Pengantar Teknologi Informasi, Jakarta : Salemba Infotek

[17] Tika, I. 2012. IbM Untuk Petani Anggur di Desa Dencarik, Kecamatan Banjar. Bulelang Bali. Jurnal Pengabdian pada Masyarakat.

[18] Widya, L. 2012. Memberdayakan Masyarakat Menuju Peningkatan Kualitas Sumber Daya Manusia. Jurnal Pengabdian Kepada Masyarakat. Universitas Pendidikan Ganesha. Singaraja. 